\title{
BAURAN PEMASARAN DAN SHARIA COMPLIANCE TERHADAP LOYALITAS PELANGGAN
}

\author{
Ahmad Dzul Ilmi Syarifuddin', Akramunnas Akramunnas² \\ ahmaddzulilmi@gmail.com ${ }^{1}$, erossandimahesa@gmail.com² \\ Fakultas Ekonomi dan Bisnis Islam IAIN Parepare ${ }^{1}$ Fakultas Ekonomi dan \\ Bisnis Islam UIN Alauddin Makassar²
}

Received: 20 April 2020; Revised: 6June 2020; Published: 14 June 2020

\begin{abstract}
ABSTRAK
Penelitian ini mambahas pengaruh bauran pemasaran dan sharia compliance terhadap loyalitas customer mobil Avansa pada PT. Haji Kalla Cabang Alauddin yang melakukan pembelian melalui pembiayaan syariah. Sebanyak 100 sampel dipilih dengan tehnik purposive, data dianalisis menggunakan regresi berganda. hasil penelitian menyimpulkan bahwa bauran pemasaran: produk, harga , promosi, dan lokasi dan sharia compliance secara parsial berpengaruh terhadap loyalitas customer mobil Avansa pada PT. Haji Kalla Cabang Alauddin yang melakukan pembelian melalui pembiayaan syariah. Bauran pemasaran dan sharia compliance berpengaruh secara parsial terhadap loyalitas customer mobil Avansa pada PT. Haji Kalla Cabang Alauddin yang melakukan pembelian mobil melalui pembiayaan syariah.
\end{abstract}

Kata Kunci : Bauran, Sharia Compliance , Pelanggan

\section{ABSTRACT}

This study adds to the influence of marketing mix and sharia compliance on customer loyalty of Avansa cars at PT. Haji Kalla Alauddin Branch who purchases through Islamic financing. 100 samples were selected using purposive technique. Data were analyzed using multiple regression. the results of the study concluded that the marketing mix: product, price, promotion, and location and sharia compliance partially influenced the customer loyalty of Avansa cars at PT. Haji Kalla Alauddin Branch who purchases through Islamic financing. The marketing mix and Sharia Compliance partially influence the customer loyalty of Avansa cars at PT. Haji Kalla Alauddin Branch who purchases cars through Islamic financing.

Keywords: Mix, Sharia Compliance, Customer 


\section{PENDAHULUAN}

Loyalitas pelanggan dapat dicapai melalui penerapan bauran pemasaran secara konsisten. Bauran Pemasaran adalah sekumpulan kegiatan yang dilakukan perusahaan untuk mencapai tujuan pemasaran perusahaan, olehnya itu perusahaan perumusan bauran pemasaran yang tepat sudah menjadi hal yang harus dilakukan oleh perusahaan, perusahan harus lebih terbuka menerima masukan dan pendapat dari konsumen, karena kunci keberhasilan marketing adalah konsumen sebagai fokus pencapaian tujuan akhir perusahaan, yaitu pencapaian laba dari pembelian produk. Hal tersebut menuntut perusahaan untuk lebih memahami berbagai faktor yang mempengaruhi konsumen dalam pengambilan keputusan pembelian produk.

Harga (Price) merupakan salah satu bagian dari bauran pemasaran yang merupakan nilai tukar yang melekat pada kendaran atas manfaat karena memiliki dana atau menggunakannya. ${ }^{1}$ Akad Syariah menggunakan akad murabhah harga terbentuk dari akumulasi harga pokok (cost) barang di tambah margin keuntungan yang disepakati. ${ }^{2}$ Harga merupakan faktor yang sangat berpengaruh loyalitas pelanggan ${ }^{3}$. Selain itu, penetapan harga menjadi sangat penting bagi perusahaan ditengah persaingan yang begitu ketat. Harga yang ditetapkan oleh perusahaan harus mampu untuk memenuhi ekspetasi konsumen terhadap kualitas produknya. Semakin beragamnya selera dan kebutuhan konsumen menjadi tuntutan bagi produsen agar terus melakukan inovasi. Selain itu kesesuaian manfaat yang diterima konsumen juga harus diperhatikan oleh perusahaan dalam penetapan harga tersebut. Keslahan dalam penetapan harga berdampak serius bagi perusahaan, karena produk kompetitor akan selalu siap menggaet konsumen dengan menampung kekecewaan konsumen. Hal ini didukung oleh penelitian sebelumnya yang menyatakan bahwa harga yang kompetitif signifikan mempengaruhi loyalitas pelanggan. ${ }^{4}$

${ }^{1}$ Kotler, Philip \& Garry Armstrong. 2010. Prinsip-Prinsip Pemasaran, Edisi. Kedua Belas. Jakarta : Erlangga hal. 314

2 Bagya Agung Prabowo, Aspek Hukum Pembiayaan Murabahah pada Perbankan Syariah, (Yogyakarta: UII Press Yogyakarta, 2012), hlm. 25

${ }^{3}$ Evi Husniati Sya'idah Tontowi Jauhari. 2018. Pengaruh Marketing Mix Terhadap Loyalitas Pelanggan, Jurnal EkoNiKa, Vol. 3. No. 1, April 2018. Hal. 23-30

${ }^{4}$ Tengku Putri Lindung Bulan (2016) Pengaruh Kualitas Pelayanan Dan Harga Terhadap Loyalitas Konsumen Pada PT. Tiki Jalur Nugraha Ekakurir Agen Kota Langsa, Jurnal Manajemen dan Keuangan, Vol.5, No.2, November 2016 hal.592-602 
Loyalitas pelanggan juga dipengaruhi oleh Produk. Barang atau jasa yang ditawarkan oleh pemasar untuk mendapatkan daya beli, perhatian yang dimanfaatkan oleh konsumen untuk pemenuhan keinginan dan kebutuhannya disebut produk, bagi seorang marketing sangat penting untuk memahami pelanggannya terutama kebutuhan produk yang dibutuhkan oleh konsumennya, yang dilakukan melalui kegiatan mendefenisikan produknya agar sesuai dengan kebutuhan konsumen baik dari segi nilai, tampilan, kualitas, USP (Unique Selling Proposition) dan pesaingannya ${ }^{5}$. Hasil Penelitaian Muhammad Maftukhin (2012) ${ }^{6}$ membuktikan Loyalitas pelanggan bergantung pada kualitas produk. Hasil penelitian terdahulu secara nyata membuktikan lokasi merupakan faktor yang berpengaruh dan memiliki hubungan yang searah dengan loyalitas pelanggan. ${ }^{7}$

Konsumen Otomotif disulawesi selatan yang didominasi oleh penduduk muslim berjumlah 7.200 .938 jiwa $(89,63 \%)^{8}$, hal ini mengindikasikan bahwa untuk memenangkan pasar otomotif dikota makassar pemasar harus memahami prilaku konsumen muslim. Perilaku konsumen muslim dalam memilih pembiayaan dalam pembelian mobil setidaknya meliputi dua hal yaitu halalan (halal) dan thayibban (baik), konsumen muslim sangat memegang teguh aspek reliugitas dalam proses pengambilan keputusan pembeliannya, olehnya itu pihak pembiayaan harus mampu melakukan upaya yang inovatif untuk memenangkan loyalitas pelanggan muslim dikota Makassar mempertimbangkan aspek reliugitas.$^{9}$

Melihat jumlah dominasi pelanggan muslim dikota Makassar maka selain konsep marketing mix, hal yang harus diperhatikan untuk memenangkan loyalitas konsumen muslim adalah faktor mempengaruhi

${ }^{5}$ Kotler, Amstrong. 2001. Prinsip-prinsip pemasaran, Edisi keduabelas, Jilid 1. Jakarta: Erlangga.

${ }^{6}$ Maftukhin, Muhammad. 2012. Pengaruh Kualitas Pelayanan dan Kualitas Produk Terhadap Loyalitas Pelanggan di Toko Bandeng Juwana Elrina Semarang. Jurnal Fakultas Ekonomi dan Bisnis Universitas

7 Yulianto, Firman. 2010. “Pengaruh Faktor Bauran Pemasaran terhadap Pertimbangan Nasabah dalam Memilih Bank Syariah di Kota Medan." Jurnal ISSN, hlm. 1411-0199.

8 Sang Pencerah (Muhammadiyah Post) , 2014 Persentase Jumlah Umat Islam Berbagai Daerah di Indonesia, https:/ / sangpencerah.id/2014/12/persentase-jumlah-umat-islamberbagai/

${ }_{9}^{9}$ Nugraha J. Setiadi, 2013, Prilaku Konsumen, Perspektif Kontemporer pada Motif, Tujuan dan Keinginan Konsumen, Jakarta: Kencana Prenada Media Group, hal. 17 
loyalitas konsumen muslim yaitu Penerapan prinsip shariah compliance dalam aktifitas transaksi bisnis yang bebas riba (bunga) bebas gharar( unsur ketidak pastian), bebas maysir(judi), dana diinvestasikan untuk kegiatan yang halal. ${ }^{10}$ Untuk memenuhi keinginan dan kebutuhan konsumen muslim pihak Kalla Group melakukan kerjasama pembiayaan dengan beberapa Bank yang menerapkan prinsip jual beli dengan Murabahah.

Penelitian-penelitian terdahulu yang terkait dengan marketing mix dan syariah compliance menunjukan keterkaitan dalam mempengaruhi loyalitas dan keputusan pelanggan, Penelitian Wahibur Rokhman (2016) menunjukan marketing mix yang terdiri dari Faktor Produk, faktor harga, Faktor lokasi, kegiatan promotion dan sharia compliance merupakan factor factor yang mempengaruhi keputusan konsumen memilih bank umum syariah ${ }^{11}$, sejalan dengan Siti Aisyah (2017) penelitiannya menunjukkan Ketaatan pada Prinsip Syari'ah terbukti meningkatkan loyalitas pada nasabah BMT Sidogiri. ${ }^{12}$ Meski demikian beberapa penelitian masih menunjukkan inkonsistensi yakni hasil penelitian Yulianto (2010) menunjukan factor promosi dan harga tidak memiliki pengaruh terhadap keputusan dan loyalitas nasabah meski produk dan lokasi berpengaruh ${ }^{13}$.

\section{TINJAUAN PUSTAKA}

\section{Bauran Pemasaran}

Pengertian pemasaran berasal dari kata dasar "pasar" merujuk kepengertian lokasi atau tempat terjadinya transaksi jual-beli sedangkan istilah "pemasaran" merujuk kepengertian kegiatan yang dilaksanakan yang berkaitan dengan aktivitas penjualan dan pembelian suatu produk baik barang maupun jasa, secara konseptual Kotler ${ }^{14}$, memperkenalkan konsep bauran pemasaran 4 P yakni:

${ }^{10}$ Muhamad. 2004. Dasar-dasar Keuangan Islami. Yogyakarta: Ekonisia hal.52

11 Zamroni, Wahibur Rokhman(2016) Pengaruh Marketing Mix Dan Syariah Compliance Terhadap Keputusan Nasabah Memilih Bank Umum Syariah Di Kudus, Equilibrium: Jurnal Ekonomi Syariah Volume 4 Nomor 1 -XQL 2016, 97 - 113

${ }^{12}$ Asiyah, Siti (2017) Pengaruh Ketaatan Pada Prinsip Syariah (Kps) Terhadap Loyalitas Nasabah, Ekuitas: Jurnal Ekonomi dan Keuangan-Volume 1, Nomor 1, Maret 2017 : 104-121

13 Yulianto, Firman. 2010. "Pengaruh Faktor Bauran Pemasaran terhadap Pertimbangan Nasabah dalam Memilih Bank Syariah di Kota Medan." Jurnal ISSN, hlm. 1411-0199.

${ }^{14}$ Armstrong dan Kotler. 1996. Dasar-Dasar Pemasaran. Jakarta : Intermedia. 
Produk (Product). adalah apapun yang memiliki nilai tawar dari produsen untuk memenuhi kebutuhan atau keinginan pasar. Olehnya itu, produk merupakan pemahaman produsen yang subyektif atas sesuatu yang memiliki nilai ekonomi dan nilai tawar sebagai usaha pencapaian tujuan organisasi dengan cara memenuhi kebutuhan, tuntutan dan keinginan konsumen. yang mengikuti kompetensi dan kapasitas daya beli pasar. ${ }^{15}$

Harga (Price). Merupakan besaran uang sebagai kompensasi atas manfaat yang dirasakan dari produk atau jasa. besaran uang sebagai kompensasi yang dikeluarkan untuk mendapatkan atau memiliki suatu produk baik barang maupun jasa ditentukan oleh kesepakatan antara kedua belah pihak, baik pembeli maupun penjual itu sendiri. ${ }^{16}$ Bagi Perusahan penetapan harga produk berkaitan dengan usaha memaksimumkan laba, serta memperoleh pengembalian investasi atau pengembalian pada pengambilan keputusan pembelian bersih, mencegah atau mengurangi persaingan dan mempertahankan atau memperbaiki pangsa pasar. Perusahaan harus bijaksana dalam menetapkan harga karena variabel ini menjadi salah satu penentu bagi permintaan pasarnya.

Place atau Saluran distribusi berperan menyalurkan barang dan jasa serta melancarkan lalulintas barang dan jasa hingga sampai ke konsumen.

Pendistribusian barang dan jasa ke konsumen dari produsen tidaklah mudah untuk dilakukan. olehnya itu peran saluran distribusi penting. Apalagi untuk dapat menjangkau suatu pasar yang luas, dalam hal ini membutuhkan saluran distribusi yang dapat menyampaikan barang sampai ke tangan konsumen ${ }^{17}$.

Promosi (Promotion) Promosi adalah aktivitas pemasaran yang berusaha mengkomunikasikan, menginformasikan, mempengaruhi atau mengingatkan pasar sasaran atas perusahaan dan produknya agar bersedia menerima, membeli, dan loyal pada produk yang ditawarkan. Kegiatan Promosi bertujuan memperkenalkan produk baru, dan sebagai salah satu usaha mempertahankan selera konsumen .

Sharia Compliance. Sharia compliance (Kepatuhan Syariah) merupakan pengimplementasian prinsip Qurani dan Hadis, dalam transaksi financial dan

\footnotetext{
${ }^{15}$ Fandy Tjiptono, 2002 ,Manajemen Jasa, Penerbit Andi Yogyakarta Hal.95

${ }^{16}$ Basu Swastha dan Irawan, (2000), Manajemen Pemasaran Modern, Edisi 2, Yogyakarta : Liberty. Hal.147

17 Assauri (2003), Manajemen Pemasaran Jasa, jilid1, Jakarta.PT Gramedia. Hal. 2003
} 
perbankan serta bisnis lain yang terkait ${ }^{18}$. Shariah compliance adalah bentuk implementasi pertanggungjawaban pihak bank dalam pengungkapan kepatuhan lembaga keuangan terhadap prinsip shari'ah ${ }^{19}$ Dengan penegakan prinsip Sharia compliance memberi indikator serta menjadi jaminan kepatuhan bank Islam terhadap prinsip syariah.

\section{METODE PENELITIAN}

Subjek penelitian adalah customer Kalla Toyota Cabang periode tahun 2018/ 2019. Pengambilan sampel menggunakan tehnik purposive sampling dengan kriteria inklusi sampel adalah (1) customer yang membeli mobil avansa melalui pembiayaan Syariah, (2) Customer membeli mobil Jenis Avansa. Sebanyak 100 orang responden dijadikan sampel. Data dianalisis dengan menggunakan regresi berganda.

\section{HASIL PENELITIAN DAN PEMBAHASAN}

Pengujian data diperoleh melalui pengolahan data hasil penyebaran angket terhadap 100 orang responden. Hasil pengujian data telah melalui uji kualitas data yaitu uji asumsi klasik dan pengujian instrument dengan uji Validitas realibilitas, diperoleh hasil analisis regresi sebagai berikut :

Tabel. 1. Hasil Pengujian Regresi Berganda

\begin{tabular}{ll|r|r|r}
\hline Model & \multicolumn{2}{|c|}{$\begin{array}{c}\text { Unstandardized } \\
\text { Coefficients }\end{array}$} & $\begin{array}{c}\text { Standardized } \\
\text { Coefficients }\end{array}$ \\
\cline { 3 - 5 } & (Constant) & \multicolumn{1}{|c}{ B } & Std. Error & \multicolumn{1}{c}{ Beta } \\
\hline \multirow{2}{*}{ Produk } &, 119 &, 484 &, 012 &, 281 \\
& Harga &, 237 &, 019 &, 339 \\
& Promosi &, 121 &, 020 &, 161 \\
& Lokasi &, 238 &, 016 &, 412 \\
& Sharia Compliance &, 241 &, 015 &, 438 \\
\hline
\end{tabular}

Sumber Hasil Olah Data Penelitian

18 Antonio, Muhammad Syafei, Bank syariah Bagi Banker Dan Praktisi Keuangan, (Jakarta TazkiaInstitute, 1999) 12

${ }^{19}$ Ansori, -Pengungkapan Shariah compliance dan Kepatuhan Bank syariah terhadap Prinsip Shari'ahl, dalam Jurnal Dinamika Akuntasi, Vol.3, Nomor. 2, (Maret, 2001), 3 dalam http://journal.unnes.ac.id/index.php/jda (diakses 06 November 2013), 2. 
Persamaan Regresi :

$$
\begin{aligned}
& \mathrm{Y}=- \text { 0,073 + 0,119 Produk + 0,237 Harga }+ \text { 0,121 Promosi }+0,238 \text { Lokasi }+ \\
& \text { 0,241 Sharia Compliance }+\mathbf{e}
\end{aligned}
$$

\section{Pengaruh Produk Terhadap Loyalitas Nasabah}

Pengujian regresi berganda diperoleh besarnya koefisien regresi 0,119 dengan nilai $(+)$ mengindikasikan arah hubungan yang serah variabel Strategi produk terhadap tingkat loyalitas nasabah, sehingga diinterpretasikan bahwa satu satuan peningkatan kualitas produk meningkatkan loyalitas nasabah sebanyak $11,9 \%$

Pengujian signifikansi diperoleh nilai signifikansi produk sebesar 0,00 > a pada taraf 0,05 yang menegaskan ada pengaruh strategi produk terhadap loyalitas pelanggan

"Ada Pengaruh Secara Positif Dan Signifikan Strategi Produk Terhadap Loyalitas Customer Mobil Avansa Pada PT. Haji Kalla Cabang Alauddin Yang Melakukan Pembelian Mobil Melalui Pembiayaan Syariah"

Penelitian ini mendukung teori Tjiptono (2002) Strategi produk merupakan usaha penawaran barang dan jasa melalui pemahaman yang subyektif oleh produsen untuk memenuhan kebutuhan atau keinginan pasar untuk memenangkan persaingan dan daya beli pasar yang pada akhirnya menciptakan kepuasan dan loyalitas pelanggan seberapapun pesaing melakukan usaha yang sama. ${ }^{20}$ Keunggulan strategi pemasaran terhadap suatu produk sangat bergantung terhadap bagaimana produsen mampu menginterpretasikan, pengimplikasian dan memahami berbagai strategi bauran pemasaran.

Pentingnya menjamin kualitas produk secara nyata dijelaskan dalam hadits Rasulullah shallallahu alaihi wa sallam bersabda, "

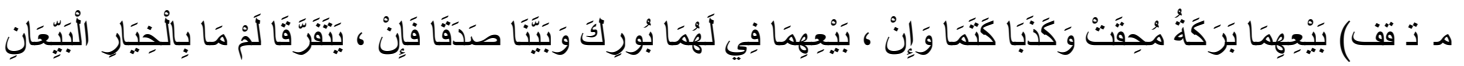
(عل ليه (كليه

"Penjual dan pembeli masih boleh memilih (untuk meneruskan transaksi atau membatalkannya) selama mereka belum berpisah. Jika keduanya jujur dan menjelaskan apa adanya, maka keduanya diberkahi dalam jual belinya. Jika

${ }^{20}$ Tjiptono, Fandy. (2002). Strategi Pemasaran. Yogyakarta hal.95 
keduanya menyembunyikan (cacat) dan berdusta, maka akan dihapus berkah pada keduanya." 21

Islam sangat peduli dengan kualitas produk yang diperdagangkan dan tidak menyembunyikan kecacatan atas produk yang dijual, pembeli harus mengetahui kondisi real dari barang yang akan dibelinnya. Hal ini berarti bahwa jual beli dalam islam harus menganut transparansi dan kejujuran terhadap kondisi produk yang dijual serta tidak mengandung unsur penipuan didalamnya.

Hasil penelitian ini sejalan dengan penelitian terdahulu yaitu Muhammad Maftukhin (2012)22 membuktikan bahwa setiap peningkatan strategi produk suatu barang maka loyalitas pelanggan terhadap produk tersebut semakin tinggi.

Pengembangan produk Avansa telah eksis dan diperkenalkan sejak Desember tahun 2003 di Indonesia, dan secara resmi dipasarkan sejak Januari 2004. Toyota Avanza mengalami adaptasi mengikuti kebutuhan dan keinginan harapan pelanggannya di Indonesia dan kota Makassar khususnya.

Produk pertama Avansa hadir dengan dua tipe yaitu tipe E dan G, menggunakan mesin DOHC 16 katup $1.300 \mathrm{cc}$ transmisi manual. Toyota Avansa terus melakukan usaha pemenuhan kebutuhan pelanggan yang saat itu mulai melirik transmisi otomatis sehingga 7 bulan kemudian Avansa merilis produk terbarunya yakni Avansa tipe $S$ dengan transmisi otomatis 4 percepatan. Penyempurnaan mesin dilakukan pada tipe ini dengan merubah kode mesin menjadi K3-VE DOHC 16 katup 1.300 cc menggunakan teknologi VVT-i (Variable Valve Timing-intelligent). Produsen Avansa meningkatkan keselamatan konsumen dengan menghadirkan system ABS (Antilock Braking System) pada sistem pengereman.

Pengembangan produk Avansa terus diarahkan menuju pemenuhan kepuasan pelanggan pada Juni 2006 telah dilakukan peluncuran Avanza 1.3 manual tipe E dan G yang mengalami penyempurnaan mesin berteknologi VVT-i. Pengembangan Avansa tipe ini mengalami facelift dengan melakukan penyegaran grille dan bumper depan, lampu belakang juga pilihan warna interior.

21 (HR. Bukhari, no. 1973, Muslim, no. 1532)

22 Maftukhin, Muhammad. 2012. Pengaruh Kualitas Pelayanan dan Kualitas Produk Terhadap Loyalitas Pelanggan di Toko Bandeng Juwana Elrina Semarang. Jurnal Fakultas Ekonomi dan Bisnis Universitas 
Perhatian Pelanggan pada tipe Avansa S yang meningkat membuat produsen avansa melakukan pengembangan Avansa Tipe $S$ yang dirilis pada oktober 2006 dengan mengembangkan mesin 1.3 VVT-i (3SZ-VE) dengan varian transmisi M/T dan A/T. dan juga Tipe S 1.5 VVT-i mesin 1.500 cc, yang dilengkapi sensor parkir belakang, pengembangan rem ABS, dan pelek alloy menjadi 15 inci.

Pengembangan produk terus dilakukan pada oktober 2008 Avansa mengalami pengembangan terhadap semua tipe mulai desain foglamp, bumper, center mesh bumper, roof lining, ornamen krom pada pintu belakang ( $S$ \& $G$ ). Pengembangan Produk avansa terus dilakukan hingga tahun 2009 dirilis produk avansa jenis baru yaitu tipe $1.3 \mathrm{G}$ dengan transmisi yang otomatis, pada mei 2010 pengembangn tipe 1.3 E transmisi otomatis Persaingan produk ditahun 2010 semakin gencar mendorong produsen Avansa generasi kedua yaitu All New Toyota Avanza (1.3 E, 1.3 G dan 1.5 G).dengan tampilan sporty dan fitur yang lebih komplit yang terus dikembangkan hingga tahun 2013 dilakukan pengembangan produk avansa pada sisi keamana pengemudi serta kenyamanan interior. Juni 2014 diluncurkan Avansa Luxuary dengan tampilan lebih mewah benar benar menggusung kenyamanan pelanggan sebagai temanya dengan menambah kelengkapan desain interior, eksterior dan perangkat hiburan yang dikemas lengkap.

Revolusi paling besar pada produk Avansa yaitu pada Agustus 2015, menggusung tema Grand NEW, desain dan tampilan menggunakan desain Toyota 'Keen Look'. Dengan tampilan lebih elegan dan sporty. Hingga Di awal 2019 tampilan Avanz terus mengalami perubahan mengikuti selera dan permintaan konsumen

\section{Pengaruh Harga Terhadap Loyalitas Pelanggan}

Koefisien hasil regresi variabel Harga sebesar 0,237 dengan nilai $(+)$ menunjukan arah hubungan yang serah hal ini mengindikasikan setiap satu satuan peningkatan Strategi Harga maka akan meningkatkan nilai loyalitas nasabah sebanyak $23,7 \%$

Nilai signifikansi variabel Harga sebesar $0,00<$ a pada taraf 0,05 yang menegaskan bahwa ada pengaruh strategi Harga terhadap loyalitas pelanggan

"Ada Pengaruh Secara Positif Dan Signifikan Strategi Harga Terhadap Loyalitas Customer Mobil Avansa Pada PT. Haji Kalla Cabang Alauddin Yang Melakukan Pembelian Mobil Melalui Pembiayaan Syariah" 
Penelitian ini mendukung pernyataan teori bahwa penetapan harga merupakan factor yang urgen bagi perusahaan karena harga yang dapat dijangkau oleh konsumen merupakan salah satu bentuk pemenuhan ekspektasi konsumen, jika perusahaan melakukan kesalahan dalam penetapan harga dapat berdampak serius bagi perusahaan, dengan beralihnya konsumen keproduk lain karena kompetitor lain telah siap melakukan usaha untuk merebut konsumen yang kecewa. ${ }^{23}$ Bila harga suatu barang tidak sesuai ekspektasi konsumen ( terlalu mahal) dapat berdampak pada penurunan penjual, barang tidak dilirik oleh konsumen dan ditinggalkan oleh konsumennya.

Penetapan harga dalam islam harus memenuhi prinsip adil, prinsip harga yang normal dan prinsip sesuai harga pasar. Islam menjunjung tinggi mekanisme pasar serta larangan berbuat tidak adil. ${ }^{24}$ Islam secara tegas menjunjung tinggi mekanisme pasar sebagaimana diriwayatkan Anas.ra:

"Orang-orang mengatakan, wahai Rasulullah, harga mulai mahal. Patoklah harga untuk kami? Rasulullah bersabda, 'Sesungguhnya Allahlah yang mematok harga, yang menyempitkan dan melapangkan rezeki, dan saya sungguh berharap bertemu Allah dalam kondisi tidak seorang pun dari kalian yang menuntut kepadaku dengan suatu kezaliman dalam darah dan harta" 25

Naik dan turunnya harga bisa dipengaruhi oleh prilaku adil maupun prilaku batil, salah satu contoh pergeseran harga yang disebebkan oleh prilaku tidak adil adalah turunnya penawaran akibat tidak efisiennya produksi, turunnya jumlah impor serta tekanan pasar ${ }^{26}$

Penelitian ini mendukung pernyatan penelitian sebelumnya yang menyatakan harga berpengaruh secara signifikan terhadap loyalitas pelanggan. ${ }^{27}$ Lebih lanjut Hendra Galuh Febrianto menegaskan dalam Persada

${ }^{23}$ Basu, Swastha. 2000. Manajemen Pemasaran Modern. Jakarta:PT Raja Grafindo.

${ }^{24}$ Yusuf Qardhawi, Norma dan Etika Bisnis Islam, Alih Bahasa Zainal Arifin (Jakarta:Gema Insani,1999),h.189

${ }^{25}$ HR Abu Dawud [3451] dan Ibnu Majah [2200]).

${ }^{26}$ Adiwarman A Karim, Ekonomi Mikro Islam, Edisi Ketiga (Jakarta: PT Raja Grafindo Persada,2011),h.144

27 Tengku Putri Lindung Bulan ( 2016) Pengaruh Kualitas Pelayanan dan Harga terhadap Loyalitas Konsumen pada PT. Tiki Jalur Nugraha Ekakurir Agen Kota Langsa Jurnal Manajemen Dan Keuangan, Vol.5, No.2, November 2016 
penelitiannya bahwa Strategi harga dalam penetapannya tidak selalu lebih rendah dari harga pesaingnya, karena berdampak rusaknya mekanisme pasar. ${ }^{28}$

Toyota Avansa pada segmennya memiliki harga yang sangat kompetitif, pada peluncuran perdananya, Avanza dibanderol seharga Rp 90 - 100 jutaan per unit. Untuk tahun 2019 Toyota Avanza dijulan dengan kisran harga Rp188,6 - Rp239,45 juta. Untuk memenagkan eksistensinya sebagai competitor yang unggul dalam harga Kalla Toyota cabang Alauddin memberlakukan potongan harga diskon setiap pembelian Avanza baru dengan besaran harga mulai Rp10 juta - Rp12 juta.. ${ }^{29}$

\section{Pengaruh Promosi terhadap Loyalitas pelanggan}

Besarnya koefisien regresi variabel Harga, 0,121 dengan tanda (+) menunjukan hubungan yang serah diantara kedua variabel tersebut, yang berarti setiap satu satuan peningkatan Strategi Promosi maka akan meningkatkan nilai loyalitas nasabah sebanyak $12,1 \%$

Hasil Uji signifikansi menunjukan besarnya nilai signifikansi variabel Promosi sebesar 0,00 lebih besar dari a pada taraf 0,05 yang menegaskan bahwa ada pengaruh strategi Promosi terhadap loyalitas pelanggan

"Ada Pengaruh Secara Positif Dan Signifikan Strategi Promosi Terhadap Loyalitas Customer Mobil Avansa Pada PT. Haji Kalla Cabang Alauddin Yang Melakukan Pembelian Mobil Melalui Pembiayaan Syariah"

Hasil penelitian ini mendukung teori yang dikembangkan oleh Tjiptono (2002:219) yang menyatakan bahwa kegiatan promosi adalah faktor penentu keberhasilan pemasaran. Kegiatan promosi berperan sebagai media penyebaran informasi, untuk mempengaruhi, membujuk, serta mengingatkan konsumen untuk membeli serta memiliki loyalitas terhadap produk yang ditawarkan.

Dealer resmi Toyota Kalla Cabang Alauddin melakukan berbagai kegiatan promosi promo besar besaran diawal tahun 2020 untuk pembelian Toyota baru di Makassar yang berisi DP dan cicilan, Paket Kredit Toyota Syariah, promo tukar tambah dan bonus-bonus pembelian. Selain itu

${ }^{28}$ Hendra Galuh Febrianto (2008) Strategi pemasaran pada mini market ahad dalam peningkatan volume penjualan, repository UIN Jakarta http://repository.uinjkt.ac.id/

${ }^{29}$ https:/ / www.cnnindonesia.com/teknologi/20190118132811-384-361901/mitsubishitanggapi-strategi-tahan-dan-diskon-harga-avanza 
Pelanggan Kalla Toyota dapat menikmati diskon jasa servis 20 persen dan diskon suku cadang 5 persen untuk pemeliharaan unit Toyota hingga akhir November 2019, untuk mendukung kegiatan promosi Toyota Kalla Cabang Alauddin menggunakan beberapa media periklanan website, hotline, katalog brosur, poster maupun spanduk (periklanan), serta ikut berperan dalam event pameran dagang, penggunaan media sosial dll. ${ }^{30}$

\section{Pengaruh Lokasi Terhadap Loyalitas Pelanggan}

Koefisien regresi variabel Lokasi $(0,238)$ dengan tanda $(+)$ menunjukan arah hubungan serah Strategi Pemilihan Lokasi terhadap tingkat loyalitas nasabah yang berarti setiap satu satuan peningkatan Strategi pemilihan lokasi maka akan meningkatkan nilai loyalitas nasabah sebanyak 23,8 \%

Nilai signifikansi strategi lokasi $(0,00<$ a pada taraf 0,05 yang menegaskan bahwa ada pengaruh strategi pemilihan lokasi terhadap loyalitas pelanggan

"Ada Pengaruh Secara Positif Dan Signifikan Strategi Pemilihan Lokasi Terhadap Loyalitas Customer Mobil Avansa Pada PT. Haji Kalla Cabang Alauddin Yang Melakukan Pembelian Mobil Melalui Pembiayaan Syariah"

Hasil penelitian ini sejalan dengan pendapat Assauri (2003) bahwa Strategi pemilihan lokasi memegang peran strategis dalam mekanisme pendistribusian barang dan kelancaran lalulintas barang. ${ }^{31} \mathrm{Hal}$ ini sesuai dengan keadaan lokasi PT. Haji Kalla Cabang Alauddin yang berada dipusat kota yakni dijalan Sultan Alauddin merupakan jalan utama propinsi yang menghubungkan kota Makassar dan Kabupaten Gowa. Letak gerai berada diantara pusat pertokoan yang padat penduduk dan mudah dijangkau karena aksesnya berada dijalan provinsi.

Kondisi lokasi gerai PT. Haji Kalla Cabang Alauddin yang berada diantara deretan pertokoan outomotiv dan perbengkelan sesuai dengan hukum Law of retail trade movement yang menyebutkan bahwa ketertarikan konsumen berbelanja ke lokasi pertokoan yang memiliki banyak jenis dan persediaan barang dagangan, dan memiliki reputasi sebagai lokasi yang memiliki barang bermutu dengan harga bersaing. 1990),h.17

30 Soemarsono, Peranan Pokok dalam Menentukan Harga Jual (Jakarta: Rieneka Cipta,

${ }^{31}$ Assauri (2003), Manajemen Pemasaran Jasa, jilid1, Jakarta.PT Gramedia. Hal. 192 
Pemilihan Lokasi bisnis dalam islam dikenal dengan istilah "almakanu" yang berarti tempat, dalam sebuah hadis disebutkan

"Jika engkau ingin mengerjakan sesuatu pekerjaan maka pikirkanlah akibatnya, maka jika perbuatan tersebut baik, ambillah dan jika perbuatan itu jelek, maka tinggalkanlah" (HR Ibnu Mubarak)

Dalam kaitan dengan konsep starategi pemilihan lokasi hadis tersebut diinterpretasikan untuk memilih lokasi yang baik karena lokasi yang baik akan memberi dampak yang baik bagi bisnis, sebaliknya lokasi yang jelek akan memberi dampak yang buruk bagi bisnis. ${ }^{32}$

\section{Pengaruh Sharia Compliance Terhadap Loyalitas Nasabah}

Koefisien regresi 0,241 dengan tanda $(+)$ menunjukan arah hubungan serah Sharia Compliance terhadap tingkat loyalitas nasabah mengindikasikan setiap satu satuan peningkatan Sharia Compliance maka akan meningkatkan nilai loyalitas nasabah sebanyak $24,1 \%$

Nilai signifikansi variabel Sharia Compliance sebesar $0,00<$ a pada taraf 0,05 yang menegaskan ada pengaruh strategi produk terhadap loyalitas pelanggan

"Ada Pengaruh Secara Positif Dan Signifikan Sharia Compliance Terhadap Loyalitas Customer Mobil Avansa Pada PT. Haji Kalla Cabang Alauddin Yang Melakukan Pembelian Mobil Melalui Pembiayaan Syariah"

Hasil penelitian ini mendukung teori Abdul,Qawi,Othman dan Lynn,Owen. 2001 yang menyatakan bahwa Sharia Compliance adalah syarat mutlak dari lembaga keuangan syariah. Sharia Compliance adalah bagian kepatuhan terhadap hukum Islam terdiri atas dimensi compliance, yang lebih dikenal dengan CARTER, yakni; Compliance, which means the ability to fulfi with Islamic law and operate under the principles of Islamic banking and economy merupakan syarat produk atau jasa syariah. ${ }^{33}$

32 Irmayanti Hasan, Manajemen Operasional Perspektif Integratif, (Malang: UIN Maliki Press, 2001), hal.72-73.

33 Abdul,Qawi,Othman dan Lynn,Owen. 2001. The Multi Dimensionality of CARTER Model to Measure Customer Service Quality (SQ) in Islamic Banking Industry ( A Study in Kuwait Finance House). International Journal of Islamic Financial Service. Vol. 3, No. 4 
Hasil penelitian ini sesuai dengan janji Allah SWT yang tertulis dalam surat alHadad ayat 11:

"Barang siapa yang meminjami Allah pinjaman yang baik, Allah akan melipat gandakan baginya dan di sisi-Nya pahala berlimpah dan lebih mulia."

Alhadid ayat 11 mengisyaratkan bahwa amal baik seperti memberikan hutang tanpa bunga akan mendapat keberkahan, keberkahan yang diperoleh PT. Haji Kalla Cabang Alauddin berupa loyalitas pelanggan

Hasil penelitian Metawa dan Almossawi (1998) menyimpulkan keputusan nasabah memilih lembaga keuangan di dominasi oleh factor reliugitas dan kepatuhan terhadap prinsip islam dianggap sebagai kriteria seleksi yang paling penting. ${ }^{34}$ Penelitian dari Omer (1992) ${ }^{35}$ dan Hegazy (1995) ${ }^{36}$ juga menyimpulkan factor reliugitas sebagai factor yang berpengaruh terhadap pemilihan lembaga keuangan islam.

Komitmen Kalla Group sebagai induk dari PT. Haji Kalla Cabang Alauddin melakukan langkah strategis untuk meraih loyalitas dan segmentasi consumen muslim Kalla Toyota melakukan kerja sama dengan beberapa Bank dalam pembiayaan mobil Avanza menggunakan mekanisme Akad Murabhah.

\section{Pengaruh Simultan Bauran Pemasaran (Produk, Harga , Promosi, Dan Lokasi ) dan Sharia Compliance Terhadap Loyalitas}

Uji simultan (F) dalam penelitian ini bertujuan untuk membuktikan pengaruh simultan variabel bauran pemasaran (produk, harga, promosi, dan lokasi ) dan Sharia Compliance terhadap loyalitas ditunjukkan tabel 2 berikut:

${ }^{34}$ Metawa dan Almossawi (1998) Banking behavior of Islamic bank customers: Perspectives and implications, Banking behavior of Islamic bank customers: Perspectives and implications, International Journal of Bank Marketing 16(7):299-313.

35 Omer, H. S. H. 1992. The implications of Islamic beliefs and practice on the Islamic financial institutions in the UK: case study of Albaraka International Bank UK. unpublished $\mathrm{PhD}$ thesis. Economics Department. Loughborough University.Loughborough.

36 Hegazy, I. 1995. An Empirical Comparative Study between Islamic and Commercial Banks' Selection Criteria in Egypt. International Journal of Commerce and management5(3): 4661. 
Tabel 2. Hasil Uji Simultan

\begin{tabular}{|c|c|c|c|c|c|c|}
\hline \multicolumn{7}{|c|}{ ANOVA $^{a}$} \\
\hline \multicolumn{2}{|c|}{ Model } & Sum of & $\mathrm{df}$ & Mean & $\mathrm{F}$ & Sig. \\
\hline \multirow{3}{*}{1} & Regression & 144,621 & 5 & 28,924 & 296,521 &, $000^{\mathrm{b}}$ \\
\hline & Residual & 9,169 & 95 & ,098 & & \\
\hline & Total & 153,790 & 100 & & & \\
\hline
\end{tabular}

a. Dependent Variable: loyalitas

b. Predictors: (Constant), Sharia Compliance, promosi, harga, Lokasi,

Produk

Hasil uji simultan bauran pemasaran (produk, harga, promosi, lokasi) dan Sharia Compliance terhadap loyalitas Customer mobil Avansa pada PT. Haji Kalla Cabang Alauddin yang melakukan pembelian mobil melalui pembiayaan syariah, menunjukkan nilai $\mathrm{f}$ sig. sebesar $0,00<$ dari a pada taraf 0,05 hal ini membuktikan bahwa :

"Bauran pemasaran (Produk, Harga, Promosi, Dan Lokasi) Dan Sharia Compliance berpengaruh secara simultan terhadap loyalitas customer mobil Avansa pada PT. Haji Kalla Cabang Alauddin yang melakukan pembelian mobil melalui pembiayaan syariah"

Hasil penelitian ini sejalan dengan pendapat Muhammad, 2004 yang menyatakan bahwa disamping Bauran Pemasaran yang terdiri atas Price, Promotion, Place, Product berpengaruh terhadap keputusan nasabah memilih lembaga keuangan syariah hal yang sangat urgen Penerapan shariah compliance yang diterapkan secara konsisten dalam pengelolaan dana nasabah. ${ }^{37}$ Regulasi tentang kepatuhan syariah (sharia compliance) merupakan aspek terpenting dalam industri keuangan syariah baik dari segi pengelolaan maupun segi manajerial, sehinggga keberadaan Dewan Pengawas Syariah merupakan suatu keharusan bagi lembaga keuangan yang menerapkan prinsip syariah.

Hasil penelitian ini mendukung penelitian Zamroni, Wahibur Rokhman(2016) yang menyatakan marketing mix yang terdiri dari produk,

${ }^{37}$ Muhamad. 2004. Dasar-dasar Keuangan Islami. Yogyakarta: Ekonisia 
harga, lokasi, promosi dan Sharia Compliance secara signifikan mempengaruhi keputusan nasabah memilih bank umum syariah di Kudus ${ }^{38}$

\section{SIMPULAN}

Disimpulkan bauran pemasaran (Produk, Harga , Promosi, Dan Lokasi ) dan Sharia Compliance secara parsial berpengaruh terhadap loyalitas Customer mobil Avansa pada PT. Haji Kalla Cabang Alauddin yang melakukan pembelian melalui pembiayaan syariah.

Bauran pemasaran (Produk, Harga , Promosi, dan Lokasi ) dan Sharia Compliance berpengaruh secara simultan terhadap loyalitas customer mobil Avansa pada PT. Haji Kalla Cabang Alauddin yang melakukan pembelian mobil melalui pembiayaan syariah

\section{DAFTAR PUSTAKA}

Abdul,Qawi,Othman dan Lynn,Owen. 2001. The Multi Dimensionality of CARTER Model to Measure Customer Service Quality (SQ) in Islamic Banking Industry ( A Study in Kuwait Finance House). International Journal of Islamic Financial Service. Vol. 3, No. 4;

Adiwarman A Karim, Ekonomi Mikro Islam, Edisi Ketiga (Jakarta: PT Raja Grafindo Persada,2011);

Ali Hasan, 2008, Marketing, Media Utama, Yogyakarta.

Ansori, -Pengungkapan Shariah compliance dan Kepatuhan Bank syariah terhadap Prinsip Shari'ahl, dalam Jurnal Dinamika Akuntasi, Vol.3, Nomor. 2, (Maret, 2001), 3 dalam http://journal.unnes.ac.id/index.php/jda (diakses 06 November 2013);

Antonio, Muhammad Syafei, Bank syariah Bagi Banker Dan Praktisi Keuangan , (Jakarta TazkiaInstitute, 1999) 12;

Ari Wibowo, "Pengaruh Kualitas Layanan, Harga dan Lokasi terhadap Keputusan Pembelian di D'stupid Baker Surabaya, (Surabaya: Jurnal Ilmu dan Riset Manajemen, Vol. 3, No. 12 Sekolah Tinggi Ilmu Ekonomi Indonesia (STIESIA), 2014,;

Armstrong dan Kotler. 1996. Dasar-Dasar Pemasaran. Jakarta : Intermedia.;

Asiyah, Siti (2017) Pengaruh Ketaatan Pada Prinsip Syariah (Kps) Terhadap Loyalitas Nasabah, Ekuitas: Jurnal Ekonomi dan Keuangan-Volume 1, Nomor 1, Maret 2017 : 104-121;

38 Zamroni, Wahibur Rokhman(2016) Pengaruh Marketing Mix Dan Syariah Compliance Terhadap Keputusan Nasabah Memilih Bank Umum Syariah Di Kudus, Equilibrium: Jurnal Ekonomi Syariah Volume 4 Nomor 1 -XQL 2016, 97 - 113; 
Assauri (2003), Manajemen Pemasaran Jasa, jilid1, Jakarta.PT Gramedia. Hal. 2003;

Bagya Agung Prabowo, Aspek Hukum Pembiayaan Murabahah pada Perbankan Syariah, (Yogyakarta: UII Press Yogyakarta, 2012;

Basu Swastha dan Irawan, (2000), Manajemen Pemasaran Modern, Edisi 2, Yogyakarta : Liberty.

Basu, Swastha. 2000. Manajemen Pemasaran Modern. Jakarta:PT Raja Grafindo. Persada;

Evi Husniati Sya'idah Tontowi Jauhari. 2018. Pengaruh Marketing Mix Terhadap Loyalitas Pelanggan, Jurnal EkoNiKa, Vol. 3. No. 1, April 2018. Hal. 23-30

Fandy Tjiptono, 2002 ,Manajemen Jasa, Penerbit ANDI YOGYAKARTA hal.95;

Gari Nurahman dan Mustika Sufiati Purwanegara (2013) Marketing Strategy of Narapati Indah Syariah Hotel, The Indonesian Journal of Business Administration, Vol. 2, No. 3, 2013, hal 293-30;

Hegazy, I. 1995. An Empirical Comparative Study between Islamic and Commercial Banks' Selection Criteria in Egypt. International Journal of Commerce and management5(3): 46-61.

Hendra Galuh Febrianto (2008) Strategi pemasaran pada mini market ahad dalam peningkatan volume penjualan, repository UIN Jakarta;

HR Abu Dawud [3451] dan Ibnu Majah [2200]);

HR. Bukhari, no. 1973, Muslim, no. 1532);

Irmayanti Hasan, Manajemen Operasional Perspektif Integratif, (Malang: UIN Maliki Press, 2001), hal.72-73;

Kotler dan Keller. 2009. Manajemen Pemasaran. Jilid I. Edisi ke 13 Jakarta: Erlangg;

Kotler, Amstrong. 2001. Prinsip-prinsip pemasaran, Edisi keduabelas, Jilid 1. Jakarta: Erlangga;

Kotler, Philip \& Garry Armstrong. 2010. Prinsip-Prinsip Pemasaran, Edisi. Kedua Belas. Jakarta : Erlangga

Maftukhin, Muhammad. 2012. Pengaruh Kualitas Pelayanan dan Kualitas Produk Terhadap Loyalitas Pelanggan di Toko Bandeng Juwana Elrina Semarang. Jurnal Fakultas Ekonomi dan Bisnis Universitas;

Metawa dan Almossawi (1998) Banking behavior of Islamic bank customers: Perspectives and implications, Banking behavior of Islamic bank customers: Perspectives and implications, International Journal of Bank Marketing 16(7):299-313;

Muhamad. 2004. Dasar-dasar Keuangan Islami. Yogyakarta: Ekonisia;

Nugraha J. Setiadi, 2013, Prilaku Konsumen, Perspektif Kontemporer pada Motif, Tujuan dan Keinginan Konsumen, Jakarta: Kencana Prenada Media Group, hal. 17; 
Omer, H. S. H. 1992. The implications of Islamic beliefs and practice on the Islamic financial institutions in the UK: case study of Albaraka International Bank UK. unpublished $\mathrm{PhD}$ thesis. Economics Department. Loughborough University.Loughborough;

Sang Pencerah (Muhammadiyah Post) , 2014 Persentase Jumlah Umat Islam Berbagai Daerah di Indonesia,

Soemarsono, Peranan Pokok dalam Menentukan Harga Jual (Jakarta: Rieneka Cipta, 1990),h.17;

Tengku Putri Lindung Bulan (2016) Pengaruh Kualitas Pelayanan Dan Harga Terhadap Loyalitas Konsumen Pada PT. Tiki Jalur Nugraha Ekakurir Agen Kota Langsa, Jurnal Manajemen Dan Keuangan, Vol.5, No.2, November 2016 hal.592-602;

Yulianto, Firman. 2010. "Pengaruh Faktor Bauran Pemasaran terhadap Pertimbangan Nasabah dalam Memilih Bank Syariah di Kota Medan." Jurnal ISSN, hlm. 1411-0199;

Yusuf Qardhawi, Norma dan Etika Bisnis Islam, Alih Bahasa Zainal Arifin (Jakarta:Gema Insani,1999),h.189;

Zamroni, Wahibur Rokhman(2016) Pengaruh Marketing Mix Dan Syariah Compliance Terhadap Keputusan Nasabah Memilih Bank Umum Syariah Di Kudus, Equilibrium: Jurnal Ekonomi Syariah Volume 4 Nomor 1 -XQL 2016, 97 - 113; 